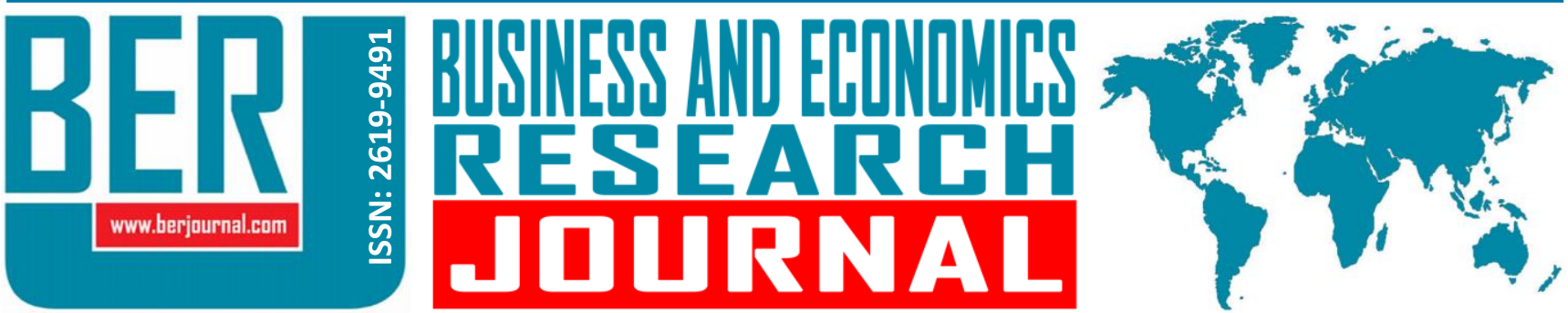 \\ Business and Economics Research Journal Vol. 12, No.1, $2021 \quad$ pp. 17-32 \\ doi: $10.20409 /$ berj.2021.308
}

\section{Household Level Inflation Rates and Inflation Inequality in Turkey ${ }^{1}$}

\author{
Ugur Akkoc $^{\mathrm{a}}$, Burca Kizilirmak
}

Abstract: This paper aims to explore the distribution of inflation rates at the household level and estimate their determinants using the Household Budget Surveys. It derives the household level inflation rates using the democratic price index and analyzes inflation inequality and its persistency. The main contributions of the paper are as follows: (i) to determine inflation inequality by examining the distribution of householdspecific inflation rates calculated by the democratic price index, (ii) to examine new dimensions of inflation inequality in Turkey by income groups and household characteristics, (iii) to estimate the micro-level determinants of household inflation rates in Turkey. Results suggest that inflation rates are lower for the rich than for the poor, and the distribution of inflation has worsened the income inequality in Turkey. This analysis provides rich information for monetary policymakers. Households have different responses to price changes or monetary policy tools because of their unique characteristics and economic conditions. Thus, we need to know how inflation rates differ at the household level in order to understand how monetary policy and inflation affect the well-being of households.

Keywords: Consumption, Inflation, Inflation Inequality, Monetary Policy, Household Economics

JEL: E31, E21, I31, D30

Received : 19 September 2020

Revised : 02 December 2020

Accepted : 30 December 2020

Type : Research

\section{Introduction}

Inflation is an important indicator of well-being due to its effects on household purchasing power and cost of living. On the other hand, households have diverse consumption bundles and therefore face different inflation rates. Using an average price index in calculations of inflation rates like the ones reported by official statistical institutes prevents identifying different purchasing power levels of households. Thus, to understand how monetary policy and inflation affect households' well-being, we need to understand how inflation rates differ at the household level.

The unequal distribution of inflation is an important dimension of economic inequality because it is a channel between income and consumption inequalities. It shapes how income inequality will be transformed into consumption inequality. The income of each individual or household turns into consumption contingent on their purchasing power. In this relationship, because inflation is the sole determinant of the depreciation of purchasing power, inflation inequality can determine whether a given income distribution leads to more equal or unequal consumption distribution. Studies of consumption inequality examine the response of consumption responds to income shocks (Blundell \& Preston, 1998;

a Asst. Prof., PhD., Pamukkale University, Faculty of Economics and Administrative Sciences, Department of International Trade and Finance, Pamukkale, Turkiye, uakkoc@pau.edu.tr (ORCID ID: 0000-0002-9949-2097)

b Prof., PhD., Ankara University, Faculty of Political Sciences, Department of Economics, Ankara, Turkiye,

Ayse.Burca.Kizilirmak@politics.ankara.edu.tr (ORCID ID: 0000-0003-3247-7586) 
Pendakur, 2001; Primiceri \& Van Rens, 2009) as well as the distribution of consumption (Lise \& Seitz, 2011; Meyer \& Sullivan, 2013; Blundell, Pistaferri \& Saporta-Eksten, 2016). Whether income and consumption inequality track each other is another critical issue in the literature (Krueger \& Perri, 2006; Jappelli \& Pistaferri, 2010; Aguiar \& Bils, 2015). However, these studies often ignore the relationship between inequalities of income and consumption and inflation distribution. Inflation determines the purchasing power of incomes and how much of household income can be consumed. Thus inflation is important in determining the difference between consumption and income inequality as well as heterogeneity of the saving ratios. Figure 1 shows the trend of income and consumption inequalities in Turkey measured with the standard Gini index for the period covered by this study.

Figure 1. Income and Consumption Inequalities in Turkey

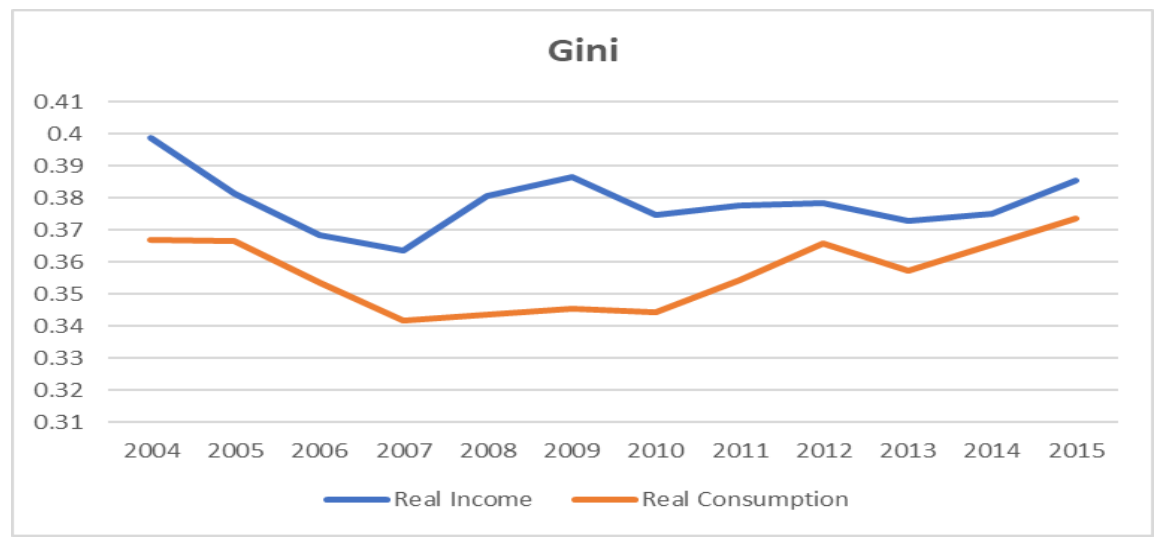

Note: Real consumption calculated as total expenditure deflated by official CPI.

This study aims to identify the various dimensions of inflation inequality in Turkey between 2004 and 2016. It develops a rich data set to examine the distribution of inflation among households, inflation inequality between and within groups, persistency and determinants of inflation. In order to examine in detail the distribution of inflation, household-specific inflation rates are calculated from the consumption patterns of each household and price series. Two methods are then used for aggregating household inflation rates to find the average inflation rate: plutocratic (used by official statistical institutions) and democratic price indices. The differences between them are then discussed. The democratic price index obtained in this step constitutes the basic index used in the rest of the study. Inflation inequality and the persistency of this inequality are analyzed using the democratic index while whole-population inequality is examined using various inequality measures. Finally, the determinants of household-specific inflation are considered in terms of various demographic and socio-economic variables.

The next section briefly reviews the literature. The third section presents the data and methods. The findings related to inflation inequalities and determinants of inflation are in the fourth and fifth sections, respectively. The fifth section concludes the paper.

\section{Literature Review}

Inflation inequality that shapes other economic inequalities among households is one of the leastinvestigated economic inequalities. One reason for the limited literature on inflation inequality could be that microdata required are rarely available. The pioneering works on this issue, namely Hobijn and Lagakos (2005) and Baldini (2005), are concerned with the overall distribution of inflation. Hobijn and Lagakos (2005) emphasize that differences in household consumption patterns and differences in the price increases for specific goods result in inflation inequality. Consequently, US inflation rates for 1987-2001 vary considerably between households. They conclude that household-specific inflation rates are significantly different from average inflation, particularly because of variation in education, health, and fuel prices. They show that the cost of living has increased for specific demographic groups, such as the elderly and poor households, while 
the persistence of inequality is weak. Baldini (2005), who computed household-specific inflation rates in Italy from budget surveys to examine their distribution, reports similar findings. This supports the conclusion that some demographic groups are systematically exposed to higher inflation than the average. Another striking finding is that inflation in Italy favors the poor. This conclusion that high-income people face higher inflation rates is among the few reported results in the literature. From their examination of a richer consumer data set obtained from Scantrack markets, Kaplan and Schulhofer-Wohl (2017) determined that inequality was more likely to be due to heterogeneity in price increases. They also used inter-group decomposition and regression methods to show that inflation has had an increasing effect on income inequality in the USA.

Studies of between-group inflation inequalities date back to an earlier period. Michael (1979) and Hagemann (1982) were the first to examine differences in price changes between groups in the USA, followed by Amble and Stewart (1994), Garner, David, and Mary (1996), Idson and Miller (1999). The findings on how inflation varies across income groups differ according to the country examined. For example, Fritzer and Glatzer (2007) reported declining inflation across all income groups in Austria, Lopez and Perry (2008) found that inflation favored low-income groups in Latin America, whereas Breuer and Mehrhoff (2009) reported no significant difference between income groups in Germany.

Other studies report that inflation varies across household types (e.g., Fritzer \& Glatzer, 2007) and that the number of children substantially reduces household inflation rates (Baldini, 2005). Finally, household head demographics can affect inflation rates. For example, Fessler and Fritzer (2013) reported higher inflation rates if the household head is employed, while Okidi and Vincent (2010) found no differences for household head gender.

There are only a few studies on inflation inequality in Turkey, all of which focus on measuring heterogeneity between income groups and find that inflation is lower in higher-income groups (Gürsel \& Şak, 2008; Yüncüler, 2013; Gürsel \& Acar, 2015). Using 2004-2015 HBS (Household Budget Statistics) data, Akçelik (2016) concluded that inflation is lower in high-income groups while Gürsel and Kavuncu (2017) found that household inflation increased as families became poorer between 2003 and 2017. According to Akçelik (2016), price changes in housing and food harm the poor, whereas only transportation inflation harms the rich. Almost all these studies used the standard calculation method of TURKSTAT (Turkish Statistical Institute) and focused on differences between income groups, whereas this study aims to contribute to the literature by examining the distribution of household inflation in Turkey calculated using different indices. The main contributions are as follows: i) to determine inflation inequality by examining the distribution of householdspecific inflation rates calculated by the democratic price index; ii) to derive a chained volume index-free from year bias; iii) to examine new dimensions of inflation inequality in Turkey by income groups and household characteristics; iv) to estimate the micro-level determinants of household inflation rates in Turkey.

\section{Data and Methodology}

Inflation determines how a household's cost of living changes. Therefore, it significantly affects household purchasing power. Household-specific inflation rates are used to measure the household-level effects of inflation and analyze its distribution across households. This section explains how to measure household-specific price indices and an aggregate price index derived from household-specific indices. Household-level inflation was calculated by weighting the price of commodities that households consume according to the share of each commodity in the household's budget, using the Laspeyres formula as follows:

$$
P_{t}^{h}=\sum_{i=1}^{91} w_{i, t-1}^{h} \frac{P_{i, t}}{P_{i, t-1}}
$$

In equation (1), superscript $h$ represents each household while subscript $i$ represents each of the 91 commodity groups. $P_{i, t}$ is the price of the ith commodity in year $t$. So, $P_{t}{ }^{h}$ is the household-specific price index of each household, and $w_{i, t}$ is the budget share of each commodity. Equation (2) shows how household price indices are aggregated: 


$$
P_{t}=\frac{1}{H} \sum_{h=1}^{H} W^{h} P_{t}^{h}
$$

Here, $P_{t}$ is the aggregate price index derived from household-specific indices.

There are two main ways to aggregate price index, namely democratic and plutocratic indices. If the weights of all households are equal to their total expenditure, one can measure the plutocratic index. This index give more weight to households that have greater expenditures in the measurement of inflation. It implicitly assumes that inflation determined dominantly by richer households. Consequently, the prices faced by high-expenditure households have more effect on the aggregate index, which leads to biasing aggregate index in favor of high expenditure groups, hence the term plutocratic index, meaning "dominance of the wealthy". Official statistical institutes such as TURKSTAT use the plutocratic index like other statistical institutes.

On the other hand, the second method of aggregation, the democratic index, weights all households equally regardless of their expenditure or income levels. Prais (1959) offers that there is no need to treat households asymmetrically in the measure of inflation. The democratic index is the unweighted one. This study uses the democratic index calculated by equation $(2)$ and equal weights $\left(W^{h}=1\right)$. Unless otherwise specified, inflation in this study refers to the percentage change in the democratic price index.

Turkey's official price index is calculated by combining data from several surveys (Household Budget Survey - HBS, Tourism Survey, and Institutional Population Expenditure Survey) and administrative records. This study calculated indices using the HBS for 2004-2017 because the contributions of the other surveys are negligible. The advantage of the chain-weighted index is that each new year is counted as a base year, so consumption baskets and weights are renewed each year, while changes in the prices of commodities are calculated in relation to the previous year. We believe that this approach avoids base-year bias.

In short, this study calculates household-level inflation rates from the chain-weighted price index and aggregates them using the democratic approach. The yearly household data used in this study comes from TURKSTAT HBS, which records household consumption expenditures on each commodity, income, employment status, and demographic characteristics of individuals annually. Commodities in HBS are disaggregated according to the five-digit COICOP classification. Prices of commodities compiled by TURKSTAT are published at a four-digit COICOP classification level, creating a potential mismatch. To eliminate this, we regrouped household expenditures at the four-digit level of commodities.

\section{Plutocratic, Democratic Inflation Rates and Inflation Inequality}

Figure 2 presents the inflation rates of democratic and plutocratic price index calculated by (1) and (2), together with TURKSTAT's official CPI. What is striking in this figure is that the behavior of aggregate inflation changed after 2009. Two patterns are evident until 2009. First official CPI inflation was lower than the other two measures. In this period, a degree of substitution bias is compatible with the literature (e.g., Cage \& Jackman, 1999: 0.15; Hobijn \& Lagakos, 2005: 0.2). Second, democratic inflation is higher than plutocratic inflation until 2009, which indicates that low-spending groups face higher inflation rates than the average. After 2009, a considerable decrease in differences between the three series accompanies the fall in inflation rates. Another result is that all three inflation rates vary over the period studied.

Another way to examine the effect of inflation inequality on consumption distribution is the plutocratic gap, which is the difference between the democratic and plutocratic inflation rates. It refletcs the bias of CPI caused by the consumtion inequality of the society. The plutocratic gap is determined by the dispersion of household expenditure. The sign of the plutocratic gap shows whether price changes affect lowincome groups more or less than high-income groups (Izquierdo, Ley \& Ruiz-Castillo, 2003). A positive plutocratic gap means that the goods favored by the richer households experience higher than average inflation and necessities have lower than average (Ley, 2005). When plutocratic inflation is higher than democratic inflation, it means that households that spend more than the average have to cope with higher 
inflation rates. A positive plutocratic gap indicates an equalizing effect of inflation on consumption distribution.

Figure 2. Annual Inflation Rates

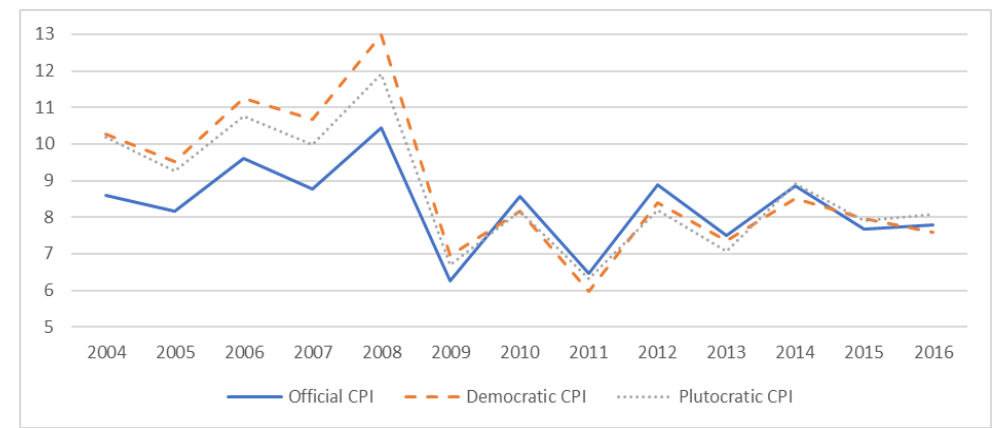

Source: Authors' own calculations form the HBS data.

Table 1. Plutocratic Gaps by Years

\begin{tabular}{ccccc}
\hline Year & $\begin{array}{c}\text { Democratic } \\
\text { Inflation }\end{array}$ & $\begin{array}{c}\text { Plutocratic } \\
\text { Inflation }\end{array}$ & $\begin{array}{c}\text { Plutocratic } \\
\text { Gap }\end{array}$ & $\begin{array}{c}\text { Plutocratic } \\
\text { Gap (\%) }\end{array}$ \\
\hline $\mathbf{2 0 0 4}$ & 10.27 & 10.17 & $-\mathbf{0 . 0 9}$ & $-\mathbf{0 . 9 3}$ \\
$\mathbf{2 0 0 5}$ & 9.51 & 9.26 & $-\mathbf{0 . 2 5}$ & $\mathbf{- 2 . 7 8}$ \\
$\mathbf{2 0 0 6}$ & 11.24 & 10.76 & $-\mathbf{0 . 4 7}$ & $-\mathbf{4 . 4 1}$ \\
$\mathbf{2 0 0 7}$ & 10.67 & 9.96 & $-\mathbf{0 . 7 0}$ & $-\mathbf{7 . 0 8}$ \\
$\mathbf{2 0 0 8}$ & 12.96 & 11.91 & $\mathbf{- 1 . 0 5}$ & $\mathbf{- 8 . 8 3}$ \\
$\mathbf{2 0 0 9}$ & 6.95 & 6.69 & $-\mathbf{0 . 2 6}$ & $-\mathbf{3 . 9 7}$ \\
$\mathbf{2 0 1 0}$ & 8.15 & 8.18 & 0.02 & 0.34 \\
$\mathbf{2 0 1 1}$ & 5.98 & 6.32 & 0.34 & 5.42 \\
$\mathbf{2 0 1 2}$ & 8.40 & 8.18 & -0.22 & $-\mathbf{2 . 7 3}$ \\
$\mathbf{2 0 1 3}$ & 7.36 & 7.07 & $-\mathbf{0 . 2 9}$ & $-\mathbf{4 . 1 5}$ \\
$\mathbf{2 0 1 4}$ & 8.51 & 8.91 & 0.40 & 4.50 \\
$\mathbf{2 0 1 5}$ & 7.95 & 7.90 & $-\mathbf{0 . 0 4}$ & $-\mathbf{0 . 6 1}$ \\
$\mathbf{2 0 1 6}$ & 7.58 & 8.06 & 0.481 & 6.06 \\
Average & $\mathbf{8 . 8 9}$ & $\mathbf{8 . 7 2}$ & $-\mathbf{0 . 1 7}$ & $\mathbf{- 1 . 4 7}$ \\
\hline
\end{tabular}

Source: Authors' own calculations form the HBS data.

The plutocratic gaps in Turkey are presented in Table 1. As Table shows, the plutocratic gap in Turkey was mostly negative from 2004 to 2016. Thus, except for 2010, 2011, 2014, and 2016, low-expenditure groups had to cope with higher-than-average inflation rates. The gap varied between -1.05 and 0.481 and averaged -0.17 ( 1.47 percent of the plutocratic index). These findings are in line with many other studies in the literature, for example, 0.09 in Austria (Fritzer \& Glatzer, 2007), -0.3 in Spain (Ley, 2005), from 2.3 to 663 during its hyperinflation period in Argentina (Lodola et al., 2000), between +2.5 and -2.1 in Uganda (Okidi \& Vincent, 2010), between +1.4 and -1.6 for South Africa (Oosthuizen, 2007), and -0.3 for Poland (Leszczynska \& Halka, 2012) and for Czech households (Hait \& Janksy, 2014). Literature suggests that the magnitude of the gap is higher in high-inflation periods irrespective of the sign. It is inferred from the table that plutocratic gap of Turkish CPI on the period of 2004-2016 is relatively higher than other developing countries. Table 1 also shows that the plutocratic gap in Turkey was highest in 2007 and 2008. According to Ley (2005), it may reflect greater consumption inequality.

\subsection{Inflation Inequality by Income Groups}

In this section, we use the democratic price index to discuss whether household level inflation varies significantly across income groups in Turkey. Inflation inequalities derived using household-specific inflation 
rates are presented in Figure 3. It shows three alternatives of standart measures on inter-group inequalities. They are ratios of inflation rates faced by different groups of population. For example, $80 / 20$ measurement is the ratio of inflation rates of two groups: The first $80 \%$ of population and first $20 \%$ of population based on household income. Likewise 90/50 and 50/10 measurements are the ratios of different income groups in population. The calculated $80 / 20,90 / 50$, and $50 / 10$ measures of inflation inequality changed considerably during the $2004-2016$ period. The $80 / 20$ ratio, which indicates inequality in the overall distribution (inequality between the top and bottom quintiles), was 1.3 on average. It reveals that the inflation rate of the richest 20 percent was only 30 percent higher than the inflation rate of the poorest 20 percent. The 50/10 ratio that measures inflation inequality within the lower half is much higher than the $90 / 50$ ratio, which is a measure of inequality in the richer half. This result shows that inflation was much more unequally distributed in the lower half, which had higher inflation. All inequality measures decreased significantly between 2010 and 2012.

Figure 3. Three Measures of Inflation Inequalities

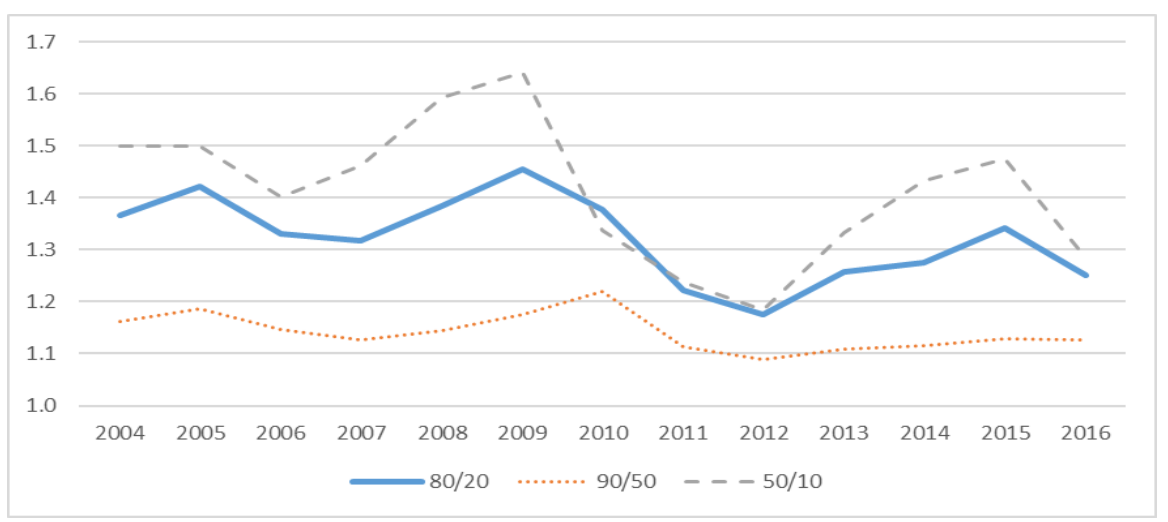

Note: Blue line represents the ratio of the inflation rates of poorest $\% 80$ to poorest $\% 20$. As the same way, red (gray) line represents the ratio of the inflation rates of poorest $\% 90$ (half) to poorest half (\%10).

For a more detailed analysis of inflation inequality, we also calculated average inflation rates of population groups in deciles. Firstly, households were divided into ten groups according to their disposable income, and the inflation rates for each income group were calculated separately. Figure 4 shows the relationship between average real annual income and inflation rates by presenting the average cumulative price indices in 2010 and 2016 for each income group. The chart clearly proves that inflation disfavors poorer households since inflation rates steadily fall from the poorest 10 percent to the richest 10 percent of households. This result implies that inflation reduces the purchasing power of lower-income groups more than that of higher-income groups. Thus, other factors, such as saving ratios of different income groups remaining constant, inflation inequality leads to more unequal distribution of consumption than distribution of income. Another significant result is shown in Figure 4 is that difference in price index between the poorest and the richest increased from 12 points in 2010 to 16 points in 2016.

This variation of inflation with income has been widely discussed in the literature about Turkey. Gürsel and Şak (2008) report that the inflation difference between the top and bottom quintiles was about 5 points in 2003-2008. Gürsel and Acar (2015) extended this study to find that the difference reached 18 points by 2014. For the same period, Yüncüler (2013) and Akçelik (2016) reported that the annual inflation rate for the poorest 20 percent was 0.87 and 0.78 points higher than the richest 20 percent. Thus, our findings are consistent with the literature.

To understand the dynamics of inflation inequalities, we begin from the two main sources of heterogeneity. First, there is heterogeneity in household consumption baskets. Secondly, price changes in goods are different. Thus, the amount of consumption of each good and the inflation of that good shapes household-specific inflation rates. We therefore first calculated the different consumption baskets of 
households. 2016 consumption shares of different income groups are shown in Table 2. The first column of the table presents the expenditure shares on average. Housing and Food and Non-Alcoholic Beverages had the highest share by far, while transportation was the other major component on average. Overall, basic needs, such as nutrition, housing, and clothing (Food and Nonalcoholic Beverages, Alcoholic Beverages and Tobacco Products, Clothes and Shoes, Housing, Transportation) accounted for more than three- quarters of average household expenditure. Education, Health, Entertainment, and Culture had the lowest shares. The fact that these groups have the lowest share highlights the importance of social insurance and state dominance in education and health in general.

Figure 4. Cumulative Price Indices by Income Groups from Poor to Rich $(2003=100)$

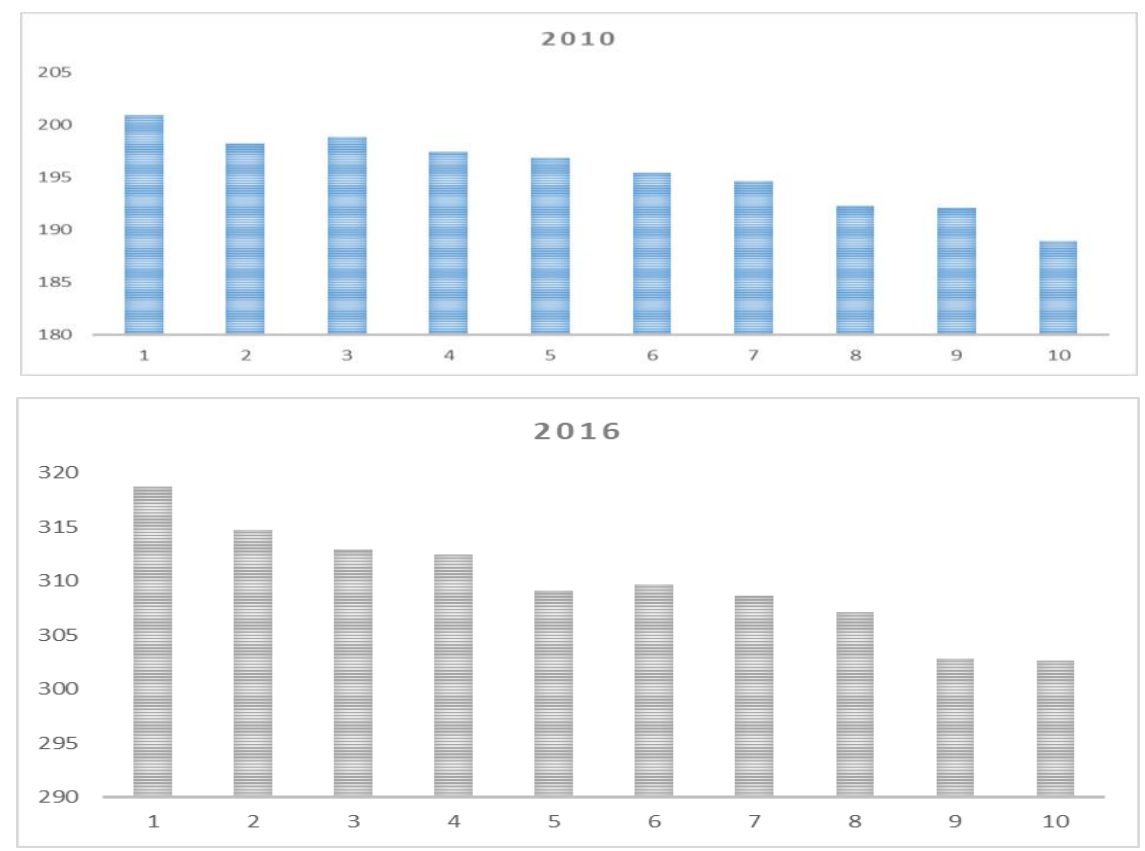

Source: Authors' own calculations form the HBS data.

As Table 2 shows, the first notable finding concerning income groups is that the shares of food and housing groups in the household basket decrease with income level. In 2016, food had 32.5 percent for the lowest income group but only 17.4 percent for the highest. Alcoholic beverages and tobacco and housing showed similar differences. On the other hand, high-income groups spend more on all the other goods groups than low-income groups, the highest difference observed in education. The share of education for the highest income group (2.60\%) is 8.67 times higher than that for the lowest income group $(0.3 \%)$ although education has very low share in the budget. This difference reflects the private education effect. Thus although education share in household expenditures is relatively low in general, we observe that the rich spend much more than the poor on the education of their children. The gap between budget shares of health expenditures is lower than that of education, but they are still sizable.

The second source of inflation heterogeneity is the price changes of the twelve main commodity groups. Appendix 1 shows how the inflation rates of the main groups deviated from the average inflation over the study period. It highlights that only two main groups have lower inflation rates than the average unexceptionally: Communication, and Clothes and Shoes. It is noteworthy that the housing inflation rate was much higher than the average inflation rate until the financial crisis, but it fell below average after that. This confirms previous findings on house prices during crisis periods (Reinhart \& Rogoff, 2008). Inflation in Food and Non-Alcoholic Beverages was above average, except in the first two years and the last one. Because this group and housing are a major budget component for low-income households, differential inflation feeds the unequal consumption distribution. This supports the claim that increasing overall inflation, food, and housing expenditure widens income inequality. 
Household Level Inflation Rates and Inflation Inequality in Turkey

Table 2. Budget Shares of the Main Commodity Groups (2016)

\begin{tabular}{lccccccc}
\hline & \multicolumn{7}{c}{ Income Groups } \\
\hline Commodities & All & 1 & 2 & 3 & 4 & 5 & Price Index \\
\hline Food and Beveridges & 25.78 & 32.50 & 27.50 & 24.50 & 22.10 & 17.40 & 204.3 \\
Alcholic Bev. and Tobacco & 5.00 & 4.80 & 5.56 & 5.53 & 5.10 & 3.88 & 409.2 \\
Clothes and Shoes & 4.68 & 3.92 & 4.62 & 4.86 & 4.84 & 5.62 & 94.4 \\
Housing & 29.70 & 34.30 & 30.32 & 28.67 & 27.77 & 24.73 & 248.6 \\
Furniture & 5.90 & 5.00 & 5.80 & 6.00 & 6.20 & 6.70 & 108.6 \\
Health & 1.40 & 1.30 & 1.43 & 1.33 & 1.37 & 1.79 & 114.4 \\
Transportation & 11.80 & 7.48 & 10.78 & 12.81 & 14.40 & 16.81 & 184.7 \\
Communication & 3.40 & 2.63 & 3.37 & 3.88 & 4.02 & 3.94 & 42.7 \\
Entertainment and Culture & 2.00 & 1.40 & 1.72 & 2.10 & 2.35 & 3.20 & 156.1 \\
Education & 1.20 & 0.30 & 0.60 & 1.00 & 1.50 & 2.60 & 202.7 \\
Rastaurants and Hotels & 5.35 & 3.50 & 4.84 & 5.64 & 6.43 & 7.48 & 318.2 \\
Other Goods and Services & 3.33 & 2.49 & 3.17 & 3.39 & 3.65 & 4.50 & 177.2 \\
\hline Source: Authors' own calculations form the HBS data. & & & & &
\end{tabular}

\subsection{Inflation Inequality by Socioeconomic Characteristics}

Figure 5 shows the difference in price indices for different socio-economic groups in Turkey. For example, car ownership has the biggest impact on prices: the price index was 9 and 18 percentage points lower in 2010 and 2016, respectively, for households with at least one car than households without a car. Similarly, households living in large houses also had lower inflation rates. As owning a car and a large house are valid proxies for income, this finding supports our previous finding that inflation is lower for richer households. Similarly, white-collar workers face since inflation rates 7 percentage points lower than average for these households. Both an employed head of the household and the women's employment in the household reduces household specific inflation. On the other hand, inflation was 5 percentage points above average for households headed by a woman.

Figure 5. Inflation Difference by Socioeconomic Groups

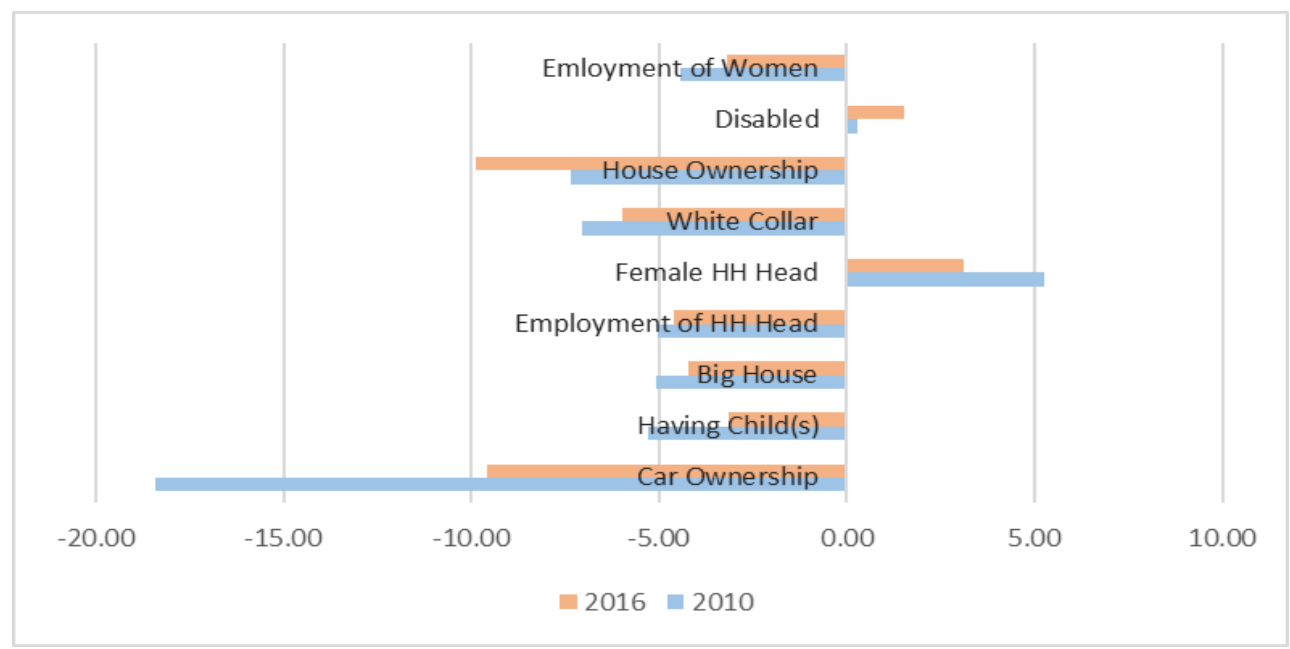

Source: Authors' own calculations form the HBS data.

\subsection{Persistency of Between-Group Inequality}

Another critical question is whether inflation differences between groups are permanent. For example, what is the chance that households with above-average inflation now face higher inflation again next year? Likewise, will a current difference in inflation rates favor the same group next year? The answer 
to these questions, namely the persistence of inequality, is examined by two analyses. The first method is to compare inflation rates of households in consecutive years. However, several technical issues must be overcome before a detailed discussion. Because HBS uses annual cross-sectional data, individual households cannot be tracked longitudinally. Therefore, we made the restrictive assumption that consumption baskets are the same for the following year to derive following-year inflation rates for households in the 2015 survey. The disadvantage of this method is that it prevents the monitoring of substitution effects. However, there is a no better option to measure the persistence of inflation inequality to the best knowledge of the authors.

Figure 6. Persistency of Inflation Inequality

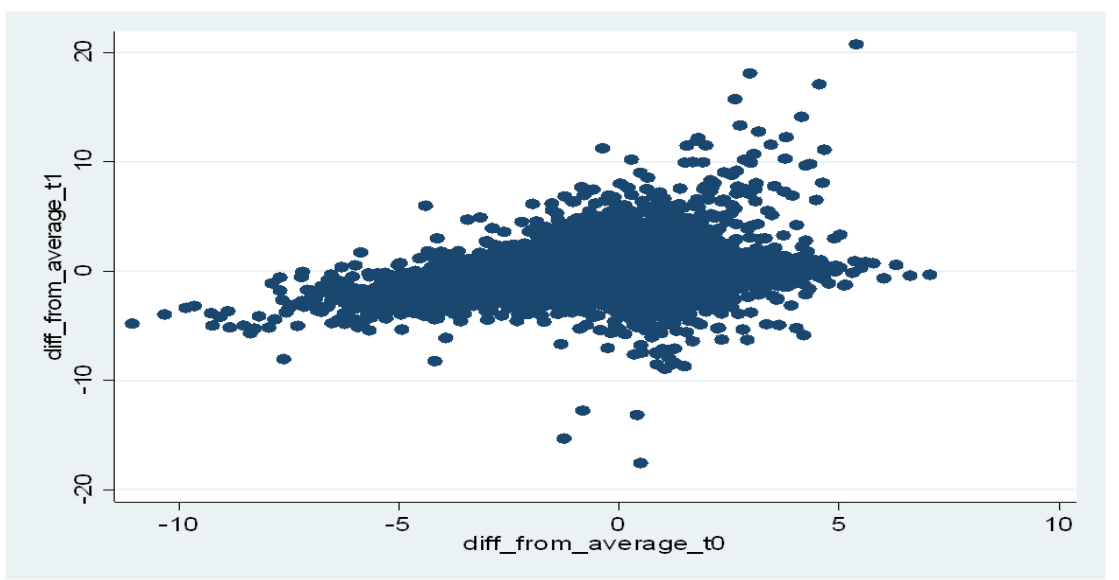

Source: Authors' own calculations.

Figure 6 shows how household-level inflation deviates from the average in 2015 along the horizontal axis and the hypothetical inflation rates for 2016 along the vertical axis. The relationship between $t$ and $t+1$ inflation rates provides information about the persistence of inequality. Figure 6 indicates that there is no complete persistency because this would be reflected in a 45-degree trend, whereas the figure'strend in the figure is quite different. The next-period inflation of households with low inflation in the first period was concentrated below the average. Similarly, households on the positive side of the horizontal axis were also concentrated on of the vertical axis's the positive side. Thus, the relative positions of households in 2015 tend to continue in the following year, albeit at a diminishing pace. The positive trend was also more robust at the extremes.

Figure 7. Persistency of Between-Group Inequalities

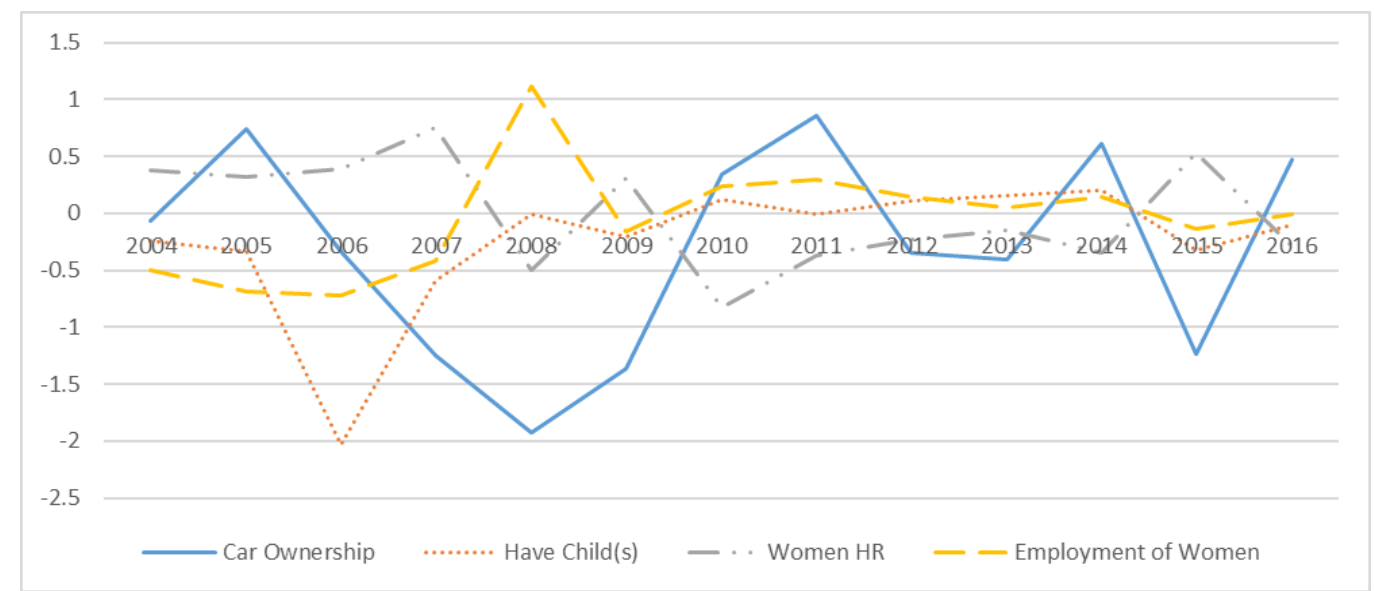

Note: All lines represent the differences between inflation rates of the two relevant groups over the years. For example, blue line shows that the difference of inflation rates between households with one or more cars and households without a car. 
The second method to examine persistency of inflation inequality is to track the inflation rates of groups in time. Figure 7 clearly shows that the differences did not follow a specific pattern. Generally, there were both negative and positive differences, while the variances decreased since 2010. The analyses in this section indicates that there is mild persistence of inflation inequality at household level but this is not due to the socio-economic group the household belongs to. One might speculate that the persistency comes from parts of their consumption patterns that do not change from year to year.

\section{Determinants of Household-Level Inflation Rates}

In this section, we estimated the demographic and socio-economic determinants of householdspecific inflation rates were obtained using the weights of the goods in each budget and price changes of these goods. HBS gives some micro-level information about types and composition of households, income, and endowments at the household level. It also provides information about age, education, and employment status at the individual level. Using this data, we estimated household-level inflation rates using the following function:

$$
\begin{gathered}
\text { Inflation }_{h}=f(\text { Demographics of Household Head, Income, Household Type, } \\
\text { House Properties, Employment Conditions })^{2}
\end{gathered}
$$

Definitions of explanatory variables are given in Appendix 2. Descriptive statistics can be found in Table 3. The table reveals that there is one disabled person in every ten households on average, 69 percent of the household heads and 27 percent of the wives are employed, and 13 percent of the household heads are women.

Table 3. Descriptive Statistics

\begin{tabular}{lccccc}
\hline Variable & Observation & Mean & Std. Dev. & Min. & Max. \\
\hline Disabled & 126,548 & 0.10 & 0.31 & 0 & 1 \\
Employment of HH Head & 126,548 & 0.69 & 0.46 & 0 & 1 \\
Tenancy & 126,548 & 0.22 & 0.42 & 0 & 1 \\
Big House & 126,548 & 0.06 & 0.24 & 0 & 1 \\
Number of Children & 126,548 & 1.27 & 1.44 & 0 & 21 \\
Number of Adults & 126,548 & 2.53 & 1.09 & 0 & 18 \\
White Collar & 126,548 & 0.18 & 0.38 & 0 & 1 \\
Employment of Women & 126,548 & 0.27 & 0.45 & 0 & 1 \\
Female HH Head & 126,548 & 0.13 & 0.33 & 0 & 1 \\
\hline
\end{tabular}

OLS (Ordinary Least Squares) estimation results are presented in Table 4. Controlling for income and other characteristics reversed the gender-related results we obtained in section $4 \mathrm{~b}$. Estimation results show that inflation is significantly lower for households with a female head. However, among the income quantiles, it is significant only for the lowest income group. Other results of the estimation are consistent with our previous findings. Variables of the number of children and the number of adults are both negative and significant in the whole sample. As for the effects of the number of children and number of adults, our findings align with the literature (Baldini, 2005; Fessler \& Fritzer, 2013; Kaplan \& Schulhofer-Wohl, 2017). The impact of the number of children in the household on household inflation is higher than the number of adults. However, this disinflationary effect mainly comes from low and middle-income groups. 
Table 4. Estimation Results for Household-Specific Inflation Rates

\begin{tabular}{|c|c|c|c|c|c|c|}
\hline Variable & $\begin{array}{l}\text { Whole } \\
\text { Sample }\end{array}$ & $\begin{array}{l}\text { First } \\
\% 20\end{array}$ & $\begin{array}{c}\text { Second } \\
\% 20\end{array}$ & $\begin{array}{l}\text { Third } \\
\% 20\end{array}$ & $\begin{array}{c}\text { Fourth } \\
\% 20\end{array}$ & $\begin{array}{l}\text { Fifth } \\
\% 20\end{array}$ \\
\hline Female HH Head & $-0.156^{* * *}$ & $-0.220 * * *$ & -0.145 & -0.158 & -0.122 & -0.001 \\
\hline Employment of HH Head & -0.033 & -0.026 & 0.032 & -0.063 & $-0.140 * *$ & -0.045 \\
\hline Employment of Women & 0.033 & -0.034 & 0.037 & 0.066 & 0.070 & -0.047 \\
\hline Disabled & 0.005 & -0.003 & 0.036 & 0.018 & 0.007 & -0.048 \\
\hline Number of Children & $-0.059 * * *$ & $-0.072 * * *$ & $-0.093 * *$ & -0.027 & $-0.039 *$ & -0.021 \\
\hline Number of Adults & $-0.023^{*}$ & -0.002 & $-0.056 *$ & -0.0002 & -0.006 & $-0.046 * * *$ \\
\hline Tenancy & $0.173 * * *$ & $0.162 * * *$ & $0.277^{* * *}$ & $0.185^{* *}$ & 0.063 & $0.088^{*}$ \\
\hline Big House & -0.044 & -0.120 & -0.203 & $-0.218^{*}$ & -0.035 & 0.039 \\
\hline White Collar & $-0.164 * * *$ & 0.166 & -0.098 & $-0.322 * * *$ & -0.023 & $-0.217 * * *$ \\
\hline \multicolumn{7}{|l|}{ Year Dummies } \\
\hline 2005 & $-0.752 * * *$ & $-1.023 * * *$ & $-0.778 * * *$ & $-0.755^{* * *}$ & $-0.470 * * *$ & $-0.669 * * *$ \\
\hline 2006 & $0.962 * * *$ & $1.471^{* * *}$ & $1.207^{* * *}$ & $0.904^{* * *}$ & $0.798 * * *$ & $0.360 * * *$ \\
\hline 2007 & $0.398 * * *$ & $1.257 * * *$ & $0.873 * * *$ & $0.402 * *$ & -0.059 & $-0.806 * * *$ \\
\hline 2008 & $2.710 * * *$ & $3.994 * * *$ & $3.493 * * *$ & $2.882 * * *$ & $1.995 * * *$ & $0.573 * * *$ \\
\hline 2009 & $-3.334^{* * *}$ & $-2.686 * * *$ & $-3.073^{* * *}$ & $-3.350 * * *$ & $-3.645^{* * *}$ & $-4.075 * * *$ \\
\hline 2010 & $-2.118^{* * *}$ & $-1.883^{* * *}$ & $-2.023 * * *$ & $-2.123^{* * *}$ & $-2.220 * * *$ & $-2.341 * * *$ \\
\hline 2011 & $-4.296 * * *$ & $-4.286 * * *$ & $-4.282 * * *$ & $-4.417 * * *$ & $-4.329 * * *$ & $-4.086 * * *$ \\
\hline 2012 & $-1.885^{* * *}$ & $-1.377^{* * *}$ & $-1.666^{* * *}$ & $-1.934 * * *$ & $-2.048 * * *$ & $-2.496 * * *$ \\
\hline 2013 & $-2.924 * * *$ & $-2.462 * * *$ & $-2.719 * * *$ & $-2.959 * * *$ & $-3.106 * * *$ & $-3.465 * * *$ \\
\hline 2014 & $-1.779 * * *$ & $-1.564^{* * *}$ & $-1.731 * * *$ & $-1.883 * * *$ & $-1.902^{* * *}$ & $-1.727 * * *$ \\
\hline 2015 & $-2.348 * * *$ & $-1.750 * * *$ & $-2.251 * * *$ & $-2.571 * * *$ & $-2.632^{* * *}$ & $-2.663 * * *$ \\
\hline 2016 & $-2.731 * * *$ & $-2.895^{* * *}$ & $-2.784 * * *$ & $-2.718 * * *$ & $-2.571 * * *$ & $-2.343 * * *$ \\
\hline \multicolumn{7}{|l|}{ Income Quantiles } \\
\hline 2. Income Quantile & 0.002 & & & & & \\
\hline 3. Income Quantile & -0.058 & & & & & \\
\hline 4. Income Quantile & $-0.105^{* * *}$ & & & & & \\
\hline 5. Income Quantile & $-0.209 * * *$ & & & & & \\
\hline Constant & $10.511 * * *$ & $10.146 * * *$ & $10.396 * * *$ & $10.433^{* * *}$ & $10.544 * * *$ & $10.787^{* * *}$ \\
\hline Prob F & 0.000 & 0.000 & 0.000 & 0.000 & 0.000 & 0.000 \\
\hline Adj $R^{2}$ & 0.152 & 0.192 & 0.148 & 0.113 & 0.170 & 0.217 \\
\hline
\end{tabular}

Household-level inflation rates are higher for tenants. It can be argued that rents are mainly fixed and is the major part of the budget. For this, rents restrict the household's ability to adapt consumption to price changes or income shocks. It is possible to say that rent exposes tenants to higher inflation rates by reducing their adaptability. On the other hand, living in houses with more than three rooms has no significant effect on household inflation.

Crucially, Table 4 also shows strong negative relationship between household income and householdlevel inflation rates. The coefficient for income groups was negative and significant for the middle and highincome groups. The magnitude of the effect increases in absolute value with rising income. For example, while being in the fourth income group decreases inflation 0.10 percentage points being in the fifth group, it decreases it 0.20 percentage points compared to the first group. Therefore, households with higher income have lower inflation rates than the lowest income group and this effect strengthens with income. Moreover, if one or both parents have white-collar jobs which provide greater income on average, their household inflation is lower. In short, in lower income groups gender of household head, number of children, tenancy and occupation determine inflation, whereas it is greatly determined by the employment of household head, number of adults and occupation in higher-income groups.

Year dummies that control the economic conditions of each year are all significant. Coefficients take negative values after 2009 and are higher in absolute value between 2009 and 2011. Furthermore, the magnitude of the negative coefficients is smaller in the lower half of the income. That means the conjuncture has downward pressure on inflation after the 2008 financial crisis but more so for higher income groups. 


\section{Conclusion}

The heterogeneity of household consumption baskets and price changes results in different inflation rates for each household. Household-level inflation rates are thus household-specific and different from the average. This implies that previous analyses using aggregate inflation rates overlooked cross-sectional dispersion in inflation. This study first calculated household-level inflation rates in Turkey using a rich microdata set. It then used a chain-weighted index rather than a base-year approach to create the average price index. It also used the democratic approach, which assigns equal weights to households for aggregation. By examining the distribution of inflation and between-group differences, the study provided important results about inflation inequality in Turkey for 2004-2016. Finally, the estimated micro determinants of household inflation rates in Turkey.

One of the striking results of the study is that the distribution of inflation deepens income inequality in Turkey. Specifically, the negative plutocratic gap implies that inflation is anti-poor in Turkey. The lower inflation rates found for higher-income groups also support this conclusion. The average price index of 100 in 2003 reached 318 in 2016 for the lowest income group whereas it was only 302 for the highest income group. Also, the estimation of determinants of household-level inflation supports that result. Higher income leads to lower inflation in the upper half of the income distribution.

Lower-income households spend most of their budget on necessities such as nutrition and housing. The share of food was twice as high for them as for the highest income group. Another important finding was that education, health, and entertainment-culture spending took only 1 or 2 percent of the budget on average. It can be claimed that he main reasons were state dominance, market structure, and wide social security coverage for education and health spending. The share of public schools in the Turkish education system is about $80 \%$ in 2020 (MEB, 2020) and the share of private health expenditures in total health expenditures is $77.5 \%$ in 2014 (Sayım, 2017). Nevertheless, it is remarkable that the share of these commodities is higher for the rich than the poor, especially in education, reflecting the effect of privatization of Turkey's education system in recent years.

Secondly, inflation was also heterogeneous among household types. Starting a family and having children reduced inflation significantly. It can be argued that changes in consumption patterns after marriage and replacing luxury goods spending by spending on children's goods are the main reasons for these lower inflation rates. Households with a car or house had lower than average price increases. However, it is assertive to say that the difference in inflation was caused by the advantages of having a car or househomeownership or having a car proxy income level. Also, the findings of lower inflation for households with a car or house were mainly explained by these households' higher income.

Third, the gender of the household head makes a difference in inflation. If the head is women, inflation of that household is lower than others. Different consumption habits and priorities of women change the allocation towards necessities and lessen the effects of price increases. Finally, the differences in inflation rates between the households are weakly persistent. Nevetheless, both the size and persistence of inflation inequality were stronger before 2010.

Inflation transforms income distribution into unequal consumption. Depreciating the purchasing power of income is known as an effect of inflation. However, the effects of inflation on inequalities are not limited to this. Both the average inflation rate and how the inflation rate is distributed among households are essential issues. The main policy implication of this study is that all policies that aim to decrease economic inequalities should take into account the inflation distribution. Thus, if monetary policy's primary objective is price stability for all households, inflation heterogeneity should be taken into consideration along with aggregate inflation. The analyses in this paper provide instructive information for monetary policymakers. Monetary policy design should take into account the heterogeneity of responses for its success, and the heterogeneity of the responses to monetary policy greatly depends on households' consumption habits. 


\section{Disclosure Statements}

1. The authors of this article confirm that their work complies with the principles of research and publication ethics.

2. No potential conflict of interest was reported by the authors.

3. This article was screened for potential plagiarism using a plagiarism screening program.

\section{End Notes}

1. This paper is derived from a dissertation by Uğur Akkoç in partial fulfillment of the requirements for the Ph.D. degree.

2. Year dummies were included in the estimations. Controlling the economic conjuncture of each year by year dummies prevents biases. House and car ownership variables were excluded from the estimations as the robustness analysis indicated a strong correlation between these variables. If the house and car ownership were included in the model, then the income coefficient became insignificant.

\section{References}

Aguiar, M., \& Bils, M. (2015). Has consumption inequality mirrored income inequality? American Economic Review, 105(9), 2725-56.

Akçelik, F. (2016). Income groups and inflation in Turkey. Unpublished Master's Thesis, ODTÜ, Ankara.

Amble, N., \& Stewart, K. (1994). Experimental price index for elderly consumers. Monthly Labour Review, 117, 11-16.

Baldini, M. (2005). Inflation inequality in Italy. University of Modena and Reggio Emilia, Unpublished Manuscript.

Blundell, R., \& Preston, I. (1998). Consumption inequality and income uncertainty. The Quarterly Journal of Economics, 113(2), 603-640.

Blundell, R., Pistaferri, L., \& Saporta-Eksten, I. (2016). Consumption inequality and family labor supply. American Economic Review, 106(2), 387-435.

Breuer, C. C., \& Mehrhoff, J. (2009). Einkommensgruppenspezifische teuerungsraten. Wirtschaftsdienst, 89(11), 755.

Cage, R. A., \& Jackman, P. C. (1999). Estimated upper level substitution in the consumer price index, 1987-97. Unpublished Manuscript, Bureau Labor Statistics.

Fessler, P., \& Fritzer, F. (2013). The distribution of inflation among Austrian households. Monetary Policy \& the Economy, 3, 12-28.

Fritzer, F., \& Glatzer, E. (2007, October). Group-Specific inflation rates for Austrian households. In 10th Ottawa Group Meeting on Prices.

Garner, T., David J., \& Mary K., (1996). An experimental consumer price index for the poor. Monthly Labor Review, September, 32-42.

Gürsel, S., \& Acar, A. (2015). Yoksul ile zengin arasındaki enflasyon farkı rekor seviyede. Betam Araştırma Notu 15/177.

Gürsel, S., \& Kavuncu, F. (2017). Yoksul ile zengin arasindaki enflasyon farki devam ediyor. Betam Araştırma Notu $17 / 213$.

Gürsel, S., \& Şak, N. (2008). Her harcama düzeyi için farklı enflasyon. Betam Araştırma Notu 08/2.

Hagemann, R. P. (1982). The variability of inflation rates across household types. Journal of Money, Credit and Banking, 14(4), 494-510.

Hait, P., \& Jansky, P. (2014). Inflation differentials among Czech households. CERGE-EI Working Paper Series, (508).

Hobijn, B., \& Lagakos, D. (2005). Inflation inequality in the United States. Review of Income and Wealth, 51(4), 581-606.

Idson, T., \& Miller, C. (1999). Calculating a price index for families with children: Implications for measuring trends in child poverty rates. Review of Income and Wealth, 45(2), 217-233.

Izquierdo, M., Ley, E., \& Ruiz-Castillo, J. (2003). The plutocratic gap in the CPI: Evidence from Spain. IMF Staff Papers, 50, 100-20.

Jappelli, T., \& Pistaferri, L. (2010). Does consumption inequality track income inequality in Italy? Review of Economic Dynamics, 13(1), 133-153.

Kaplan, G., \& Schulhofer-Wohl, S. (2017). Inflation at the household level. Journal of Monetary Economics, 91, 19-38. 
Krueger, D., \& Perri, F. (2006). Does income inequality lead to consumption inequality? Evidence and theory. The Review of Economic Studies, 73(1), 163-193.

Leszczynska, A., \& Halka, A. (2012). What does the Consumer Price Index Measure? Bias Estimates for Poland. EcoMod No. 4370.

Ley, E. (2005). Whose inflation? A characterization of the CPI plutocratic gap. Oxford Economic Papers, 57(4), 634-646.

Lise, J., \& Seitz, S. (2011). Consumption inequality and intra-household allocations. The Review of Economic Studies, 78(1), 328-355.

Lódola, A., Busso, M., \& Cerimedo, F. (2000). Sesgos en el índice de precios al consumidor: El sesgo plutocrático en Argentina. Working Paper, Universidad Nacional de La Plata, Argentina.

Lopez, J. H., \& Perry, G. (2008). Inequality in Latin America: Determinants and consequences. Policy Research Working Paper, No. WPS 4504 Washington, D.C.: World Bank Group.

MEB, (2020). Milli Eğitim İstatiskleri Örgün Eğitim 2018-2019.

Meyer, B. D., \& Sullivan, J. X. (2013). Consumption and income inequality and the great recession. American Economic Review, 103(3), 178-83.

Michael, R. T. (1979). Variation across households in the rate of inflation. Journal of Money, Credit and Banking, 11(1), $32-46$.

Okidi, J., \& Vincent, N. (2010). Inflation differentials among Ugandan households: 1997-2007. Economic Policy Research Centre Research Series No:72.

Oosthuizen, M. (2007). Consumer price inflation across the Income distribution in South Africa. DPRU Working Paper No. 07-129.

Pendakur, K. (2001). Consumption poverty in Canada, 1969 to 1998. Canadian Public Policy-Analyse de Politiques, 27(2), 125-150.

Prais, S. J. (1959), Whose cost of living? Review of Economic Studies, 26, 126-134.

Primiceri, G. E., \& Van Rens, T. (2009). Heterogeneous life-cycle profiles, income risk and consumption inequality. Journal of Monetary Economics, 56(1), 20-39.

Reinhart, C. M., \& Rogoff, K. S. (2008). Is the 2007 US sub-prime financial crisis so different? An international historical comparison. American Economic Review, 98(2), 339-44.

Sayım, F. (2017). Türkiye' de sağlık ekonomisi istatistikleri ve sağlık harcamalarının gelişimi. Yalova Sosyal Bilimler Dergisi, 7(15), 13-30.

Yüncüler, Ç. (2013). Türkiye'de enflasyon gelir grupları arasında ne kadar farklılaşıyor? ìktisat ve Toplum, No. 35. 
Appendix 1. The Deviations in Main Commodity Group Inflation Rates from Average Inflation Rates

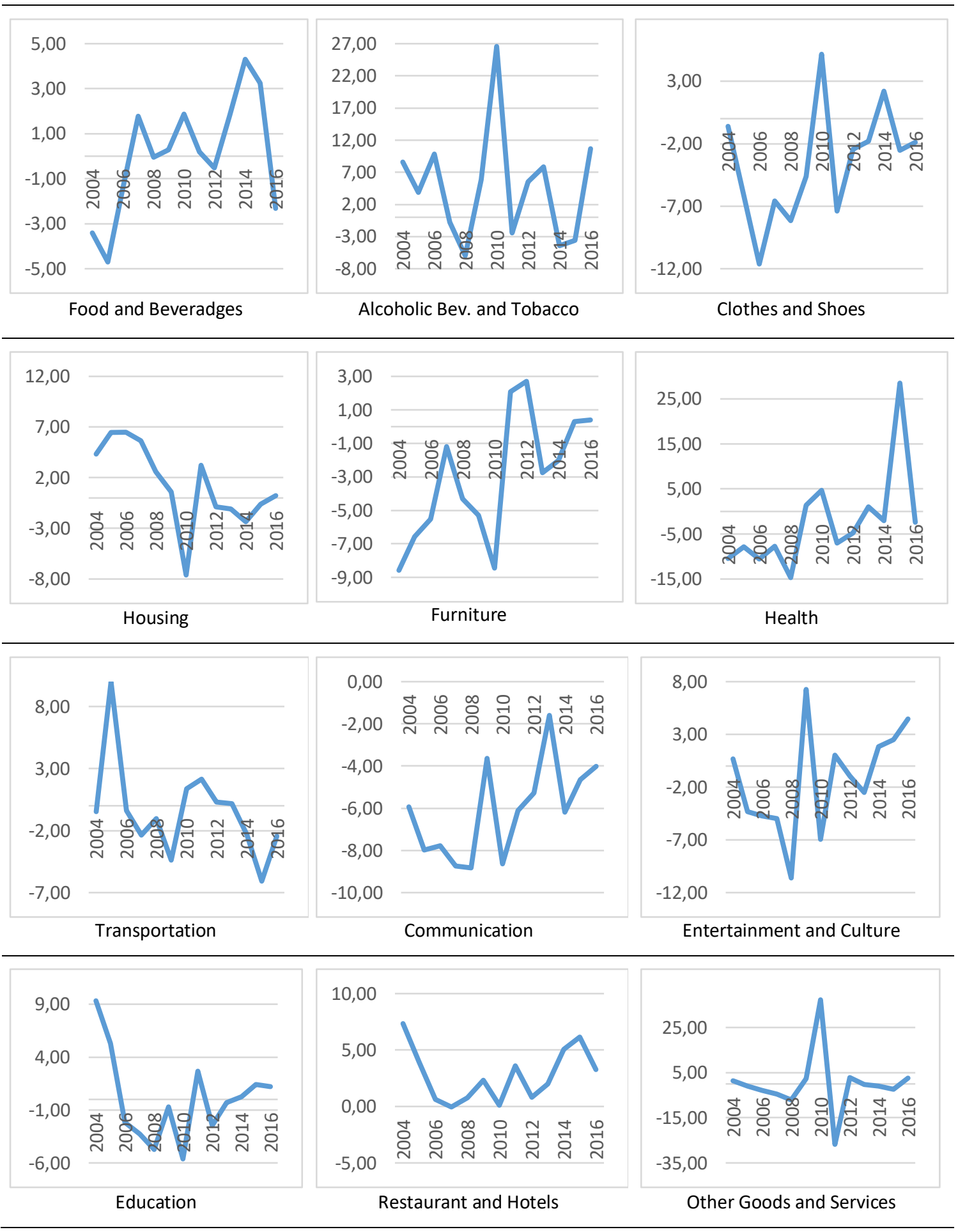


Household Level Inflation Rates and Inflation Inequality in Turkey

\begin{tabular}{|c|c|c|}
\hline Variable & Type & Description \\
\hline Inflation & Dependent Variable & Household-spesific inflation rates \\
\hline \multicolumn{3}{|l|}{ Demographics of Household Head } \\
\hline Female Household Head & Dummy Variable & $\begin{array}{c}\text { Equal to } 1 \text { if household head is female, } 0 \\
\text { otherwise. }\end{array}$ \\
\hline Employment of Household Head & Dummy Variable & $\begin{array}{c}\text { Equal to } 1 \text { if household head is in } \\
\text { employment, } 0 \text { otherwise. }\end{array}$ \\
\hline \multicolumn{3}{|l|}{ Income } \\
\hline Income Quantiles & $\begin{array}{c}\text { Categorical Variables } \\
\text { Reference Group: First } 20 \% \\
\end{array}$ & $\begin{array}{l}\text { Income group household belongs to (from } \\
\text { poorest } 20 \% \text { to richest } 20 \% \text { ). }\end{array}$ \\
\hline \multicolumn{3}{|l|}{ Household Types } \\
\hline Number of Children & & $\begin{array}{c}\text { Equal to number of children who live in the } \\
\text { household. }\end{array}$ \\
\hline Number of Adults & & $\begin{array}{l}\text { Equal to number of adult persons who live } \\
\text { in the household. }\end{array}$ \\
\hline Disabled Person & Dummy Variable & $\begin{array}{l}\text { Equal to } 1 \text { if at least one disabled person } \\
\text { lives in the household, } 0 \text { otherwise. }\end{array}$ \\
\hline \multicolumn{3}{|l|}{ House Properties } \\
\hline Tenancy & Dummy Variable & $\begin{array}{c}\text { Equal to } 1 \text { if household is tenant, } 0 \\
\text { otherwise. }\end{array}$ \\
\hline Big House & Dummy Variable & $\begin{array}{l}\text { Equal to } 1 \text { if the house that household lives } \\
\text { in have more than } 4 \text { rooms, } 0 \text { otherwise. }\end{array}$ \\
\hline \multicolumn{3}{|l|}{ Employment Conditions } \\
\hline Employment of Women & Dummy Variable & $\begin{array}{c}\text { Equal to } 1 \text { if } \mathrm{f} \text { the wife is in employment, } 0 \\
\text { otherwise. }\end{array}$ \\
\hline White Collar & Dummy Variable & $\begin{array}{c}\text { Equal to } 1 \text { if at least one of the spouses is } \\
\text { employed as a white collar worker, } 0 \\
\text { otherwise. }\end{array}$ \\
\hline Year & Dummy Variables & Dummies for all years from 2004 to 2016. \\
\hline
\end{tabular}

